\title{
Low Serum Calcium Levels in Pre-eclampsia
}

\author{
${ }^{1}$ Bushra Rashid, ${ }^{2}$ Mariam Malik Richard, ${ }^{3}$ Gul-E-Rana
}

\section{ABSTRACT}

Background: Pre-eclampsia remains the most threatening obstetric complication in Pakistan, resulting in high fetomaternal morbidity and mortality. Etiology of pre-eclampsia is not still clearly established. Association of low serum calcium levels with pre-eclampsia may be a factor in poorly nourished women, and some preventive measures may help to reduce the burden of disease.

Objective: To compare mean serum calcium levels in preeclamptic and normotensive pregnant women at third trimester of gestation.

Study design: Cross-sectional study.

Place and duration of study: The Department of Obstetrics and Gynecology, Unit-1, Sir Ganga Ram Hospital, Lahore, from July 2012 to July 2013.

Methodology: Two hundred patients were enrolled in the study. One hundred each in case and control group. History and examination performed. Proteinuria was checked by dip stick methods. Peripheral venous blood samples were taken to determine mean serum calcium levels of both the groups. Oral calcium supplementation was analyzed through stratification. Data was analyzed through SPSS by applying student's t test and calculating $p$-value.

Results: The mean serum calcium levels of the case group were $8.313 \pm 0.377$ while that of control group were $9.40 \pm 0.427$ with $p$-value 0.016 . With increasing proteinuria (determined by dipstick method) and so the severity of pre-eclampsia, a gradual fall in serum calcium levels was observed.

Conclusion: Serum calcium levels in pre-eclamptic pregnant women are lower than in normal pregnant women and so hypocalcemia is associated with pre-eclampsia.

Keywords: Pre-eclampsia, Pregnancy, Serum calcium.

How to cite this article: Rashid B, Richard MM, Gul-E-Rana. Low Serum Calcium Levels in Pre-eclampsia. J South Asian Feder Obst Gynae 2015;7(3):126-129.

Source of support: Nil

Conflict of interest: None

\footnotetext{
${ }^{1,3}$ Senior Registrar, ${ }^{2}$ Professor

${ }^{1-3}$ Department of Obstetrics and Gynecology, Sir Ganga Ram Hospital, Lahore, Pakistan
}

Corresponding Author: Bushra Rashid, Senior Registrar Department of Obstetrics and Gynecology, Sir Ganga Ram Hospital, Lahore, Pakistan, Phone: 00923334898341, e-mail: white_rose4626@yahoo.com
Date of received: 13 August 2015

Date of acceptance: 12 September 2015

Date of publication: December 2015

\section{INTRODUCTION}

Pre-eclampsia affects 3 to $5 \%$ of all pregnancies ${ }^{1}$ and is accompanied by an increase in fetal and maternal morbidity and mortality. ${ }^{2}$ Hypertension with proteinuria defines pre-eclampsia, and is a serious threat on fetal and even maternal prognosis. ${ }^{3}$ Hypertensive disorders are third (19\%) major cause of maternal mortality in Pakistan after hemorrhage $(25 \%)$ and sepsis $(21 \%) .{ }^{4}$

Pre-eclampsia is a multisystem disorder of pregnancy, the key features in the pathogenesis of pre-eclampsia include shallow, endovascular cytotrophoblast invasion in the spiral arteries, inappropriate endothelial cell activation, and exaggerated inflammatoryresponse. ${ }^{5}$ Preeclampsia can manifest as a maternal syndrome (hypertension and proteinuria with or without other multisystem abnormalities) and/or as a fetal syndrome (IUGR, reduced amniotic fluid and abnormal oxygenation). ${ }^{6}$

Recent studies show that alteration in serum levels of trace elements may play a significant role in etiology of pre-eclampsia. ${ }^{1,7}$ Significant reduction in serum calcium level is found in pre-eclamptic women. ${ }^{8,9}$ The physiological basis is that low serum calcium stimulates parathyroid hormone $(\mathrm{PTH})$ production which increases the intracellular calcium level leading to smooth muscle vessels contraction and hypertension..$^{10}$

The purpose of this study is to compare mean serum calcium levels of pre-eclamptic and normotensive pregnant women. This would help us to formulate strategies to counsel high-risk women in antenatal period for the importance of increase intake of food rich in calcium, e.g. milk and milk products and calcium supplementation. Such simple prophylactic measures may reduce the maternal and fetal morbidity and mortality associated with this serious obstetric complication.

\section{MATERIALS AND METHODS}

It was a cross-sectional study. By using nonprobability purposive sampling technique, 200 pregnant women, who gave consent for inclusion in study, were enrolled100 in group A (normotensive) and 100 in group B (preeclamptic). Pregnant women between 18 and 35 years of 
age, parity less than five with singleton pregnancy and after 28th weeks of gestation were included in the study while pregnant women with medical disorders like chronic hypertension, diabetes, hypoparathyroidism, chronic renal failure and urinary tract infection were excluded from the study.

\section{DATA COLLECTION PROCEDURE}

Two hundred patients were selected from Indoor and Emergency Department, Obstetrics and Gynecology Department, Sir Ganga Ram Hospital, Lahore. An informed consent was obtained for subjecting them to procedures and using their data in research work. Detailed history and clinical examination was performed. History of dietary intake of calcium and calcium supplementation was inquired. Blood pressure was taken by well applied sphygmomanometer placed one inch above cubital fossa placing the arms at the level of heart, diastolic reading was the 5th Korotkoff's sound (K5), taken twice 4 hours apart after half an hour of rest and proteinuria was determined on clean catch urine specimen by dipstick method, and was on a scale of ' 0 to +4 ' $(0=$ nil, $+1=$ $30 \mathrm{mg} / \mathrm{dl},+2=100 \mathrm{mg} / \mathrm{dl},+3=300 \mathrm{mg} / \mathrm{dl}$ to $2 \mathrm{~g} / \mathrm{dl},+4=$ $>2 \mathrm{~g} / \mathrm{dl}$ ). The patients with blood pressure less than 140/ $90 \mathrm{~mm} \mathrm{Hg}$ and nil proteinuria were categorized as group A (normotensive) and those with blood pressure more than 140/90 $\mathrm{mm} \mathrm{Hg}$ and proteinuria $>1$ will be grouped as group B (pre-eclamptic). Then their peripheral venous blood sample from cubital veins were collected and sent to hospital laboratory for determining serum calcium levels.

The serum calcium levels for both the groups were determined by spectrophotometric method by Beckman Coulter $X_{2}-5$ Automatic Analyzer at Sir Ganga Ram Hospital laboratory. The reagent used by the system for calcium determination was $\mathrm{CA}_{2} \times 300$ calcium reagent. The obtained data were maintained on proformas. Effect modifiers, such as calcium supplementation, were dealt through stratification.

\section{Data Analysis}

Data were entered into SPSS version ${ }^{10}$ computer software and analyzed through its statistical performance. Mean and standard deviation were calculated for age, gestational age, parity and serum calcium levels. Student's t-test were applied to compare serum calcium levels in both groups and p-value $<0.05$ was considered as statistically significant. Data were stratified for calcium supplementation.

\section{RESULTS AND DISCUSSION}

The present study enrolled 200 pregnant women, 100 in each group: group A comprised of normotensive controls and group B consisted of pre-eclapmtic case.

There was no significant difference in the age of both groups. The pre-eclamptic group presented at earlier gestation and were having low parity as compared to normotensive pregnant women (Table 1).

The analysis of the results showed that pre-eclamptic women have significantly lower serum calcium levels as compared to their normotensive controls $(8.31 \pm 0.377 \mathrm{mg} / \mathrm{dl}$ vs $9.40 \pm 0.42 \mathrm{mg} / \mathrm{dl}, \mathrm{p}=0.016)$. The present findings are similar to the results of previous studies. Two of the studies conducted in Thailand, found serum calcium levels lower in pre-eclamptic than in normal pregnant woman $(9.0 \pm 0.4 \mathrm{mg} / \mathrm{dl} \text { vs } 9.7 \pm 0.7 \mathrm{mg} / \mathrm{dl}, \mathrm{p}<0.001)^{7}$ and one in 2008 showed the same results, serum calcium levels were lower in pre-eclamptic women than that of normotensive $(8.7 \pm 0.59 \mathrm{mg} / \mathrm{dl}$ vs $8.99 \pm 0.31 \mathrm{mg} / \mathrm{dl}){ }^{8}$ A study conducted in Nigeria also determined hypocalcemia in pre-elamptic than in normal pregnant women $(9.2 \pm 1.02$ vs $9.98 \pm 0.87, \mathrm{p}=0.043){ }^{9}$

Another study conducted in India and published in 2010 also found the same results, mean serum calcium levels in normal pregnant group were $(2.45 \pm 0.18$ $\mathrm{mmol} / \mathrm{l})$ as compared with pre-eclamptic group (1.94 \pm $0.09 \mathrm{mmol} / 1){ }^{11}$

Although, a study conducted in Iran in 2008, by Golmand S and Amrabi A, showed that the mean serum calcium levels were not significantly different among normotensive vs pre-eclamptic group $(8.97 \pm 0.49$ vs $8.7 \pm$ $0.58, p=0.27)$. This difference in results might be due to smaller sample size used in that study as they only observed serum calcium levels in 52 patients in each group. 1

When comparing the present study results with previous studies conducted in different regions of the world, similar results are being obtained. It shows that racial, cultural and demographic limitation are not affecting the results so pre-eclampsia is associated with hypocalcemia and can be an important etiological factor.

Table 1: Comparisons of the clinical characteristics for the two groups of participants

\begin{tabular}{llll}
\hline Variables & Normotensive (Mean $\pm S D)$ & Pre-eclamptic (Mean $\pm S D)$ & $p$-value \\
\hline Age (years) & $25.73 \pm 1.78$ & $26.11 \pm 2.57$ & 0.071 \\
Duration of pregnancy (weeks) & $36.51 \pm 1.32$ & $35.49 \pm 1.87$ & 0.008 \\
Parity & $1.89 \pm 1.22$ & $1.12 \pm 0.79$ & 0.001 \\
\hline
\end{tabular}


Table 2: Distribution of serum calcium levels among the two groups

\begin{tabular}{lll}
\hline Serum calcium & Pre-eclamptic group (\%) & Normotensive group (\%) \\
\hline $7.0-8.0 \mathrm{mg} / \mathrm{dl}$ & 48 & 0 \\
$8.1-9.0 \mathrm{mg} / \mathrm{dl}$ & 50 & 29 \\
$9.1-10 \mathrm{mg} / \mathrm{dl}$ & 2 & 67 \\
$>10 \mathrm{mg} / \mathrm{dl}$ & 0 & 4 \\
\hline Total & 100 & 100 \\
\hline
\end{tabular}

Table 3: Serum calcium levels relation with diastolic blood pressure and proteinuria in group B; mean serum calcium level for group B: $8.35 \pm 0.39 \mathrm{mg} / \mathrm{dl}$

\begin{tabular}{llll}
\hline $\begin{array}{l}\text { Diastolic BP } \\
(\mathrm{mm} \mathrm{Hg})\end{array}$ & $\begin{array}{l}\text { Mean calcium levels for } \\
\text { diastolic BP group }(\mathrm{mg} / \mathrm{dl})\end{array}$ & Proteinuria & $\begin{array}{l}\text { Mean calcium levels for proteinuric } \\
\text { group }(\mathrm{mg} / \mathrm{dl})\end{array}$ \\
\hline Up to 100 & 8.4 & 1 & 8.4 \\
$101-110$ & 8.33 & 2 & 8.5 \\
$111-120$ & 8.1 & 3 & 8.1 \\
$>120$ & 7.8 & 4 & 7.65 \\
\hline
\end{tabular}

Table 4: Relation with calcium supplementation

\begin{tabular}{lllll}
\hline \multirow{2}{*}{ Variables } & & $\begin{array}{l}\text { Normotensive } \\
\text { (group A, } n=100)\end{array}$ & $\begin{array}{l}\text { Pre-eclamptic } \\
\text { (group B, } n=100)\end{array}$ & $\begin{array}{l}\text { Combined of total } \\
\text { participants }\end{array}$ \\
\hline Calcium supplement users (\%) & Users (\%) & $45 \%$ & $15 \%$ & $25 \%$ \\
& Nonusers (\%) & $55 \%$ & $85 \%$ & $75 \%$ \\
Mean serum calcium levels in & Users (mg/dl) & $9.515 \pm 0.383$ & $8.67 \pm 0.35$ & $9.32 \pm 0.468$ \\
calcium supplement & Nonusers (mg/dl) & $9.305 \pm 0.440$ & $8.28 \pm 0.39$ & $8.65 \pm 0.653$ \\
& Difference & $(9.515 \pm 0.383)-(9.305 \pm(8.67 \pm 0.35)-(8.28 \pm \quad(9.32 \pm 0.468)-(8.65 \pm$ \\
& & $0.440)=0.210 \mathrm{mg} / \mathrm{dl}, \quad$ & $0.39)=0.282 \mathrm{mg} / \mathrm{dl}$, & $0.653=0.67), \mathrm{p}=0.014$ \\
\end{tabular}

On analyzing serum calcium levels in detail (Table 2), $48 \%$ of pre-eclamptic patients have serum calcium levels below $8.0 \mathrm{mg} / \mathrm{dl}$. While on the other hand, $67 \%$ of the normotensive control group were having serum calcium levels above in range of $(8.1-9.0 \mathrm{mg} / \mathrm{dl})$, and no one with calcium level below $8.0 \mathrm{mg} / \mathrm{dl}$. It shows that it is not only just the mean serum calcium levels that are high in normotensive group but also it is uniformly distributed among the normotensive pregnant women.

The study data showed that with increasing the severity of pre-eclampsia measured in terms of increasing diastolic blood pressure and increasing proteinuria, the serum calcium levels were gradually decreasing (Table 3). In other words as low will be the serum calcium levels as severe would be the pre-eclampsia. These results similar to previous studies conducted in Thailand in $2008^{8}$ and also comparable to study conducted in India. ${ }^{11}$

In view of serum calcium supplementation, only $25 \%$ of the total study group ( $200=$ cases + controls $)$ were using calcium supplementation., with a quite high percentage among normotensives as compare to pre-eclamptics $(45 \%$ vs 15\%) (Table 4).

There is statistically significant difference when mean serum calcium levels compared among supplementation users collectively (both from pre-eclamptic and normotensive) with non users collectively (both from pre-eclamptic and normotensive, the mean $(9.32 \pm 0.468)$ vs $(8.65 \pm 0.653=0.67, \mathrm{p}=0.014)$.
The study data suggest that the calcium supplementation are effective in maintaing serum calcium at reasonably good level. Similar results were concluded, in Cochrane Database Systemic Review 2012, that calcium supplementation may reduce the risk of pre-eclampsia after analysis of 12 studies of good quality ${ }^{10}$ and calcium supplementation should be encouraged during pregnancy. ${ }^{12}$

\section{CONCLUSION}

Mean serum calcium levels are low in pre-eclamptic women as compare to normotensive. Hypocalcemia may be an etiological factor for pre-eclampsia calcium supplementation should be encouraged in pregnant women specifically in third trimester to reduce the risk of pre-eclampsia. Further studies should be conducted on role of calcium prophylaxis in reduction in incidence of pre-eclampsia, especially in countries, like Pakistan, where economical, maternal and perinatal mortality burden can be lessen just by simple prophylaxis.

\section{REFERENCES}

1. Golmand S, Amrabi A, Yazdian M, Pashapour N. Evaluation of serum calcium, magnesium, copper and zinc levels in women with pre-eclampsia. Iran J Med Sci 2008;33(4):231-234.

2. World Health Organization, 2004. Bethesda, MD. Global Burden of Disease for the Year 2001 by World Bank Region, for Use in Disease Control Priorities in developing countries, 
national institutes of health: WHO. Make every mother and child count. World Health Report, 2005, Geneva: World Health Organization; 2005. 2nd ed.

3. Walfisch J, Hallak M. High risk pregnancy: management options. 2nd ed. Philadelphia: WB Saunders; 2003. p. 772-789.

4. Sami S, Afridi U, Ehsan N. Magnesium sulphate as an anticonvulsant in management of eclampsia. A hospital based study. Pak J Med Res 2007;46(3):63-66.

5. Gustaaf D. Hypertension. In: James DK, Steer PJ, Weiner CP, Gonik B, Growther CA, Robson SC, editors. High risk pregnancy, Management Options, 4th ed. Elsvier; 2011. p.599-626.

6. Sibai B, Dekker G, Kupferminc M. Pre-eclampsia. Lancet 2005;365(9461):785-799.

7. Sukmapan K, Phupong V. Serum calcium and serum magnesium in normal and pre-eclamptic pregnancy. Arch Gynecol Obstet 2005;273(1):12-16.
8. Punthumapol C, Kittichotapanich B. Serum calcium, magnesium and uric acid in pre-eclampsia and normal pregnancy. J Med Assoc Thai 2008;91(7):968-973.

9. Indogun ES, Imarengiaye CO, Momoh SM. Extracellular calcium and magnesium in pre-eclampsia. Afr J Reprod Health 2007 Aug;11(2):80-85.

10. Hofmeyr GJ, Lawrie TA, Atallah AN, Duley L. Calcium supplementation during pregnancy for preventing hypertensive disorders and related problems. Cochrane Database Syst Rev 2010 Aug 4;8:CD001059.

11. Jain S, Sharma P, Kulshreshtha S, Mohan G, Singh S. The role of calcium, magnesium and zinc in pre-eclampsia. Biol Trace Elem Res 2009;133(2):162-170.

12. Moheildein AH, Doken AA, Oman YH, Idris HM. Serum calcium level as marker of pregnancy induced hypertension. Sudan JMS 2007;4:245-248. 